\section{Labour's science appointment lifts hopes for reform}

[LONDON] Britain's new Labour government has appointed John Battle, opposition spokesman on science and technology from 1994 to 1995 , as the minister responsible for science within the Department of Trade and Industry. $\mathrm{He}$ will report to Margaret Beckett, who speaks for science in Cabinet as President of the Board of Trade.

Battle, a geography graduate, is associated with the 'soft left' in the party - placing him between the traditional 'old left' and the reforming 'new Labour' of Prime Minister Tony Blair. He demonstrated an enthusiastic interest in his portfolio during his period as opposition spokesman, and his appointment is likely to be welcomed by those in the scientific community who had feared that science could end up in more conservative hands.

It could, for example, signal some significant changes in science policy. Two years ago, Battle announced after almost 50 visits and discussions with key scientists and research institutions that two "primary themes" had "clearly emerged" - the need to break with shorttermism, and the need for a "nationally coordinated science strategy". The lack of such a strategy, he argued, had resulted in a reduction of government support for science.

The latter conclusion is similar to that reached by the House of Commons Select Committee on Science and Technology in its recent inquiry into the research councils, suggesting that the topic is likely to be high on the new government's agenda.

Battle also expressed a desire to consult widely with the scientific community, announcing plans for a series of regional public meetings described as a "massive science policy consultation exercise" known as the Science 2000 Project. But this plan was dropped soon after his successor, Adam Ingram, who has been appointed to a ministerial post in the Northern Ireland office, took over the science portfolio.

Since 1995, Battle has been Labour's energy spokesman, and he will keep responsibility for energy - as well as for information technology - in his government post. Although some are concerned that political responsibility for science has been diluted as a result, Battle will be a full minister in the department. In contrast, his predecessor, Ian Taylor, while concentrating solely on science and technology, occupied a rung down the political ladder as a parliamentary under-secretary of state.

Within the Department of Education and Employment, responsibility for universities will be handled by Baroness Tessa Blackstone, the master of Birkbeck College in London, who has been appointed minister for higher education.

DavidDickson

\title{
Brookhaven contractor is sacked over tritium leak
}

[WASHINGTON] The US Department of Energy announced last week that it was sacking Associated Universities Incorporated (AUI), the contractor that has run Brookhaven National Laboratory on Long Island, New York, for 50 years, after an internal report criticized management and environmental procedures at the laboratory.

Department officials also said that the High Flux Beam Reactor (HFBR) - the research reactor whose fuel storage tank has leaked small quantities of tritium, plunging the laboratory into crisis - will not reopen until the local community is happy that it can operate safely (see Nature 386, 3; 1997).

Tara O'Toole, assistant secretary for environment, safety and health at the energy department, says that HFBR's users shared the blame for the crisis at Brookhaven. "It is wrong-headed to say that the users are not at fault," she said, when asked whether scientists who use HFBR as a neutron source would get money to move to other facilities.

"The users have to take responsibility that is the message we have to get through to scientists," says O'Toole. Environmental health and safety "is not a separate activity" for non-scientists at the lab to deal with.

Federico Peña, the energy secretary, went to Brookhaven to release the report and fire the contractor last Thursday, 1 May, only four days after the new president of AUI, Lyle Schwartz, had been appointed as interim director of the laboratory. Schwartz, who left a senior position at the National Institute of Standards and Technology to join AUI in March, says he will remain interim director at Brookhaven until a new contractor is appointed in six months.

Peña said that AUI was being sacked for "unresponsiveness" to his department's "needs and expectations for community relations and environment safety and health stewardship". But Paul Martin, chair of AUI and dean of engineering at Harvard University, said that the decision was "taken precipitously".

Appointment of a new contractor at Brookhaven will probably mean a clear-out of top management, as well as a new employer, and perhaps new terms and conditions, for the 3,200 staff.

AUI was set up in 1947 to run Brookhaven. Its other main activity is the management of the National Radio Astronomy Observatory for the National Science Foundation. The observatory has recently experienced contractual problems in building a $\$ 75$ million telescope at Green Bank, West Virginia (see Nature 384, 505; 1996).

The AUI board of trustees will meet in Washington this week to decide whether to

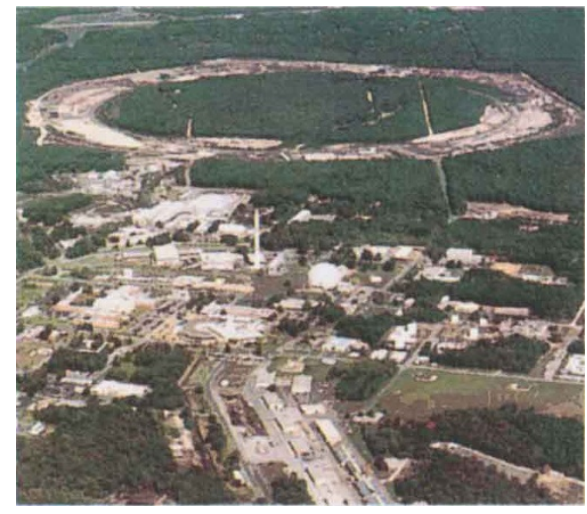

Under a cloud: users of the Brookhaven National Laboratory (above) 'must share blame'.

bid for the Brookhaven contract - as it is theoretically entitled to do - and, Schwartz said, to assess its overall future.

John Wagoner, the energy department official currently responsible for cleaning up the dirtiest nuclear waste site in the United States at Hanford, Washington, has been seconded temporarily to Brookhaven, from where he will report direct to secretary Peña. "John has proven under fire that he's a leader," says O'Toole.

Wagoner concedes that the environmental problems at Hanford and Brookhaven are "different by orders of magnitude". Brookhaven has detected a total cumulative leak of 5 curies of tritium, while Hanford discharges 6,000 curies of radioisotopes into the Columbia river each year and has around 200 million curies of waste stored in containers of varying integrity.

Peña announced that a team of inspectors from the Environmental Protection Agency is due to arrive at Brookhaven this week to perform a "full facility inspection". And Martha Krebs, assistant secretary for research at the energy department, has been given 30 days to draw up a fresh "action plan" for environmental and safety management and community responsiveness at the laboratory.

The upsets at Brookhaven are now set to spill over into the rest of the department's laboratory complex. According to Krebs, "this is an issue not just for Brookhaven but for all of our multiprogramme laboratories".

O'Toole said last week that the management of Brookhaven had "lost the public trust" and accused the lab of "problematic attitudes" to environment, health and safety issues. An example of these attitudes, she said, was that electricians carried out maintenance work on an accelerator facility at Brookhaven while wires were still live, to avoid interrupting scientific experiments.

Colin Macilwain 